\title{
THE PERCEPTIONS OF MIDDLE SCHOOL TEACHERS ABOUT THE INTEGRATION OF STEM+C: A FOCUSED-GROUP APPROACH
}

\author{
Donna L. Cellante, Robert Morris University, cellante@rmu.edu \\ Sushma Mishra, Robert Morris University, mishra@rmu.edu \\ Benjamin R. Campbell, Robert Morris University, campbellb@rmu.edu \\ Mary A. Hansen, Robert Morris University, hansen@rmu.edu \\ Gavin A. Buxton, Robert Morris University, buxton@rmu.edu
}

\begin{abstract}
It is critical that students in secondary school be exposed to STEM content integrated with computing tools to be able to gain the required confidence and skills to think and solve problems. Three focus groups were conducted with middle school STEM $+C$ teachers to determine the perceptions of these teachers about the integration of STEM $+C$ into the classroom. The middle school teachers stated that they need teacher training and a prepared curriculum in order to integrate STEM + C into the classroom.
\end{abstract}

Keywords: STEM+C, Integration, Middle School Curricula, Computing

\section{INTRODUCTION}

Science, Technology, Engineering and Mathematics (STEM) are vital to the future of our country. STEM is everywhere (Science Pioneers). According to the United States Department of Labor (2009), STEM occupations are growing at $17 \%$, while others are growing at $9.8 \%$ (Engineering for Kids.com). According to Fortune.com, the 10 fastest growing careers in the next five years are online retailing (32\%), translation services $(28 \%)$, physical/occupational/speech therapy $(25 \%)$, home health care $(24 \%)$, retirement centers $(24 \%)$, telemarketing bureaus $(20 \%)$, marketing consultant $(20 \%)$, environmental/ conservation organizations (19\%), computer system design (19\%), and portfolio management (18\%) (fortune.com/2016/06/07/the-10-fastest-gowing-careers-in-the-nextfive-years). All of the above mentioned careers are considered STEM careers.

Computing has become an integral part of STEM. STEM $+\mathrm{C}$ advances the integration of computational thinking and computing activities into early childhood through high school (preK-12) to provide a strong and developmental foundation in computing and computational thinking (National Science Foundation (NSF). How can we, as educators, make this happen?

In order to answer this question, five faculty members from the CIS, Engineering, and Education Departments at Robert Morris University (RMU) conducted a focus group with the middle school teachers at three local school districts in the STEM $+\mathrm{C}$ disciplines.

The research questions that this study addresses are:

1. What are the perceptions of middle school teachers about integrating STEM $+\mathrm{C}$ into the curriculum?

2. What are the perceptions of middle school teachers about training and resources?

3. What are the perceptions of middle school teachers about encouraging middle school females into STEM $+\mathrm{C}$ disciplines?

4.

The rest of this paper is organized as follows. The next section presents an analysis of research in the area of integrating STEM $+\mathrm{C}$. The section following the literature review presents the methodology used for this study including data collection and data analysis. The findings/discussions section are presented next, followed by the conclusions. 


\section{REVIEW OF THE LITERATURE}

The United States is losing its economic advantage over other countries (e.g., China and the European Union) and there is a fear that this trend may be further exacerbated if we fail to maintain our dominance in science, technology and math (Newman, et al., 2009). In particular, our students consistently rank lower than most other developed countries in mathematical literacy and the sciences (Kelly et al., 2013). Furthermore, given that a quarter of US students fail to graduate high school on time, it is increasingly clear that the US is failing to offer a world class education to all (Newman et al., 2009; Stetser and Stillwell, 2014). This is perhaps not too surprising; the National Center for Education Statistics reported " $61 \%$ of high school students in chemistry, and $67 \%$ in physics did not have a teacher with a major and certification in the field of study" (NCES, 2003) and, as female students also can often feel discouraged from pursuing STEM disciplines, the US is not drawing on its full potential. An ongoing challenge, therefore, is to ensure our students are both adequately educated in STEM disciplines and prepared for a future in STEM fields that increasingly employ computational skills; in an educational system continually suffering from fiscal austerity, this is obviously an increasingly difficult endeavor. There is nowhere where this is more apparent than in middle schools, where STEM $+\mathrm{C}$ is virtually nonexistent, despite the widespread introduction of technology and computers into the classroom. This indubitably has an influence on future generations of scientists and engineers, as it is in middle school where career expectations influence the future careers of potential scientists (Tai, Liu, Maltese and Fan, 2006; Knezek, 2015). More has to be done to inspire and motivate students (especially, female students) to pursue STEM careers. We believe the integration of computational skills in STEM disciplines cannot only improve the computational abilities of the students but, more importantly, improve the teaching of STEM disciplines.

The computer revolution, and the continual rise of computers and technology in all aspects of our society (including education), is arguably more significant than the industrial revolution. This has the potential to shift the focus of science education from the traditional teaching of STEM subjects, to a new paradigm including an increasing emphasis on computing and technology. However, rather than supplanting current STEM education, computers and technology are expected to be integrated more symbiotically with these STEM subjects (Best, 2014; Wilensky, Brady and Horn, 2014). This change will be necessary in a world where scientists and engineers rely on computers for both gathering, organizing and sharing scientific data, and for running models and simulations that expand the frontiers of knowledge in ways that would otherwise be unimaginable (Monroe, 2014). Furthermore, computational thinking (employing a logical thought process akin to computer science problem solving) is a critical skill in the STEM disciplines that students exposed to computing (especially in the context of STEM topics) can greatly benefit from. The role that computers play in the teaching of STEM disciplines, therefore, can go beyond the enhancement of current teaching methods and offer an entirely new way of approaching these subjects. This is especially beneficial for female students. Girls lack interest in STEM disciplines, they lack self-confidence in their ability to succeed in STEM classes, and they believe STEM careers are more for boys (AAUW, 2010; Andre et al., 1999; Herbert \& Stipek, 2005; Jacobs et al., 2002; Simpkins, Davis-Kean, \& Eccles, 2006). Girls report finding STEM subjects to be uninteresting and difficult (Miller, Blessing, and Schwartz 2006). While male students interested in pursuing a STEM career remain constant during high school (changing from 39.5 to 39.7 percent), for female students it drops from 15.7 to 12.7 percent (Cooper and Heaverlo, 2013). This is perhaps less of an ability gap than a gap in expectations and perception (Knezek, Christensen, \& Tyler-Wood, 2011), with female students thought to be more drawn to career fields perceived as being of service to others. In addition, boys demonstrate more confidence in their computing abilities and generally perform better, although the distribution with boys may be more bimodal (Jenson and Droumeva, 2016). Largely, this is believed to stem from a confidence and capability to solve problems. In particular, creativity and the ability to solve real world problems are important in STEM fields and essential for a student's STEM development (Baine, 2009; Cooper et al, 2013, National Academy of Engineering, 2008), with students indicating an interest in STEM and computing also indicating an interest in problem solving and creativity (Modi et al. 2012; Cooper et al, 2013). Through the integration of STEM and computing skills in STEM $+\mathrm{C}$, we believe we can improve problem solving skills, computational thinking, and allow more creativity into the solution of problems in STEM disciplines. The ability for students develop computer models in the classroom, to implement and explore complex STEM topics in a virtual world of their own creation, opens up the teaching possibilities immensely. There will be financial implications to integrating computing earlier into more classrooms, as well as pedagogical concerns regarding how and when computing should be introduced to complement middle school curricula, and how complex the models can become before students lose grasp of the inner mechanics of the computer simulation. 
It is critical that students in secondary school be exposed to STEM content integrated with computing tools to be able to gain the required confidence and skills to think and solve problems. Research literature suggests that early intervention is helpful to develop computational thinking perspective in students and fuel interest in STEM careers (Mishra et al., 2016). This study addresses this issue and explores the perception of middle school teachers in understanding these issues and solutions.

\section{DATA COLLECTION AND ANALYSIS}

Data was collected using three focus groups at three school districts in the western Pennsylvania region. A focus group is a group interview of approximately six to twelve people who share similar characteristics or common interests. Researchers use focus groups when they want to get more in-depth information on perceptions, insights, attitudes, experiences, or beliefs (Department of Health and Human Services, CDC, July 2008). For these focus group sessions, STEM teachers (Science; Technology Ed; Engineering; Mathematics; and Computer, Business and Information Technology) were invited via their school principals. In total, 17 middle school teachers participated in the focus group sessions. Middle school teachers were selected because of the disconnection between elementary school and high school about STEM + C integration. Also, the literature shows that career decisions are often made at the middle school level.

Each session was about 60 minutes long. From the research team, at least two members were present in all sessions. The questions template was developed and used by the research team. The same questions were asked of the STEM $+\mathrm{C}$ teachers at all three school districts. The session were recorded and detailed notes were taken. All of the data was compiled together in master document and separated based on each question that was mapped to the research question. Thematic analysis of the data was done manually by two members of the teams and verified by the remaining members of the team. Each research questions' themes are presented below.

\section{FINDINGS/DISCUSSIONS}

\section{RQ1: What are the perceptions of middle school teachers about integrating STEM+C into the curriculum?}

In response to the question, "What activities do you currently employ in your classroom that focuses on integrating STEM $+C$,?" we discovered that there are some activities taking place. Some of current activities taking place in the middle schools are geometer sketchpad; basic math with calculators; determining area, volume, and research tools; cost analysis for home repair; and mortgage analysis. One of the districts have students making battery-powered cars. In tech ed, the students do problem solving using Robot $\mathrm{C}$ and Windmills with Vex. Tech ed also does engineering design process, 3D CAD for printing, and Inventor at the basic level. General science teachers emphasize the scientific methods, declaring variables, taking measurements, and doing calculations.

In response to the question, "Do you have a special STEM+C program that you already integrate into the curriculum,?" none of the three school districts have a special STEM + C program. One school district uses Project Lead the Way for teaching computers. Project Lead the Way provides 10 units of instruction meant to empower students to lead their own discovery. The activities are for computer science, engineering, and biomedical science. The teachers in that district stated that Project Lead the Way has provided some teacher training, but not all of the teachers use it.

For the question "At what level is the integration of STEM $+\mathrm{C}$ in the curriculum starting in your school district,?" we found that STEM starts at the elementary level with library and computer class. One of the districts is currently completing a district-wide curriculum mapping exercise to determine what should be taught and when. All of the districts participated in the Hour of Code. A concern mentioned by several teachers is that students' math skills are lacking at the middle school level.

In answering the question, "What are the common areas where students struggle in the STEM+C curriculum,?" all of the teachers expressed concern about the fact that students cannot think outside the box. The students can't analyze 
data or make connections with prior knowledge. The students don't like to work on projects that don't have defined answers. The students get very frustrated if the outcome is not obvious.

\section{RQ2: What are the perceptions of middle school teachers about training and resources?}

When asked, "What is the nature of the training, if any, that you have received for integrating STEM $+\mathrm{C}$,?" most of the teachers expressed that most of what they teach is self-taught and self-initiated. One teacher commented that when they got a new 3-D printer, there was some departmental training, but that was it.

For the question, "What resources are available to you to integrate computing into your curriculum,?" the teachers had mixed answers. The teachers commented that the hardware/software they have makes it impossible to run STEM $+\mathrm{C}$ projects. They have Chrome books that lack the memory necessary to run some of the newer software. The teachers also noted that they all have computers, but that is only one computer for an entire class. They have iPad carts in their buildings, but the carts are in high demand. Scheduling in advance has been a problem since certain teachers have the carts booked daily.

In response to the question, "What resources would you like to have to help you integrate computing into your STEM curriculum,?" the teachers would like at least 12 computers in their actual classrooms. They would like lasers, plasma cutters, and AutoDesk. But they stated that what they need the "most" is a prepared curriculum - a curriculum that shows them how to use technology. The teachers want to learn ways to connect computers/STEM to full year courses despite rotations and scheduling. The teachers need job training and exposure to the newest technologies.

\section{RQ3: What are the perceptions of middle school teachers about encouraging middle school females into STEM+C disciplines?}

For the question, "How can teachers and administrators encourage middle school girls to consider STEM $+\mathrm{C}$ disciplines as a viable career option,?" the teachers stated that "their" teacher experiences and activities are the most powerful tools. However, they stated that they are not comfortable nor equipped to teach the STEM $+\mathrm{C}$ curriculum. The teachers commented that they need to find a way to motivate middle school girls. They need to instill confidence in them. However, many of the teachers didn't feel confident enough themselves to do that. Female mentors and guest speakers would help show them female role models, allowing them to aspire that same work. The teachers also mentioned that the guidance counselors often work against them by telling female middle school students to consider other fields, such as teaching and nursing. Providing field trips to local companies such as Industrial Scientific, Bayer, Covestro, FedEx, and Fisher Scientific would allow the students to see females performing actual STEM+C jobs. One teacher stated, "We can tell them about these females, but actually meeting one of them is REAL for the students."

When asked, "Do you see any difference in the learning attitudes of your male and female students towards STEM $+\mathrm{C}$,?" the teachers responded "yes." The teachers stated that girls tend to be good at science and math in $7^{\text {th }}$ grade; however, the girls lose interest by 10 th or $11^{\text {th }}$ grade. Females need to see female science and math teachers. Our district is very small and students have limited to exposure to various females. Girls tend to be more detail oriented and focused. Girls like to put things together, show purpose for the project, and verbally explain the process. Several teachers expressed that boys have more video/gaming experience. They mentioned that boys are excited about making apps. They also stated that boys don't really care about the fine details--they just want to get it done!

\section{CONCLUSION}

This study sought to capture the perceptions of middle school teachers about the integration of STEM $+\mathrm{C}$ into the middle school curriculum. Right now, not much integration is actually taking place in these school districts. These three districts are of varying sizes and economic backgrounds. However, the messages from all of the districts were pretty much the same. Some common assumptions can be made. The key to making integration happen was stated by the STEM $+\mathrm{C}$ teachers in all three school districts as "We need teacher training and a prepared curriculum!" Until that happens, it will be too difficult to move forward to integration into the middle school curriculum. Based upon the 


\section{Issues in Information Systems}

Volume 18, Issue 1, pp. 58-63, 2017

results of our study, we concluded that in order for STEM + C integration to take place at the middle school level, significant changes must be made in terms of teacher resources and teacher training.

In a future study, it would be interesting to conduct focus groups at additional school districts to determine if the stated needs remain the same.

\section{REFERENCES}

American Association of University Women. (2010). Why so few? Women in science, technology, engineering, and mathematics.

Andre, T., Whigham, M., Hendrickson, A., \& Chambers, S. (1999). Competency beliefs, positive affect, and gender stereotypes of elementary students and their parents about science versus other school subjects. Journal of Research in Science Teaching, 36, 719-747.

Best, M. L. (2014). Global computing: Thinking outside the continent. Communications of the ACM, 57(4), 27-29.

Baine, C. (2009). Engineers make a difference: Motivating students to pursue an engineering education. Springfield, OR. Bonamy Publishing.

Sanford, J. F., \& Naidu, J. T. (2016). Computational thinking concepts for grade school. Contemporary Issues in Education Research (Online), 9(1).

Cooper, R., \& Heaverlo C. (2013). Problem solving and creativity and design: What influence do they have on girls' interest In STEM subject areas? American Journal of Engineering Education, 4(1), 27-38.

Department of Health and Human Services, Center for Disease Control and Prevention (July, 2008). Data collection methods for program evaluation: Focus groups. Retrieved from www.cdc.gov/healthyyouth/evaluation/pdf/brief13.pdf.

Engineering for Kids.com. (2016). Retrieved from Engineering for Kids.com/article/02-02-2016_importanceofstem

Hebert, J., \& Stipek, D. (2005). The emergence of gender differences in children's perceptions of their academic competence. Applied Developmental Psychology, 26(2), 276-295.

Jacobs, J.E., Lanza, S., Osgood, D.W., Eccles, J.S., \& Wigfield, A. (2002). Changes in children's self-competence and values: Gender and domain differences across grades one through twelve. Child Development, 73, 509527.

Jenson, J., \& Droumeva, M. (2016). Exploring media literacy and computational thinking: A game maker curriculum study. Electronic Journal of e-Learning, 14(2).

Kelly, D., Xie, H., Nord, C. W., Jenkins, F., Chan, J. Y., \& Kastberg, D. (2013). Performance of U.S. 15-year-old students in mathematics, science, and reading literacy in an international context: First look at PISA 2012 (NCES 2014-024).

Knezek, G., Christensen, R., \& Tyler-Wood, T. (2011). Contrasting perceptions of STEM content and careers. Contemporary Issues in Technology and Teacher Education, 11(1), 92-117.

Knezek, G. Christensen, R., \& Tyler-Wood, T. (2015). Gender differences in conceptualizations of STEM career interest: Complementary perspectives from data mining, multivariate data analysis and multidimensional scaling. Journal of STEM Education: Innovations and Research 16(4), 13-19. 


\section{Issues in Information Systems}

Volume 18, Issue 1, pp. 58-63, 2017

Miller, P.H., Blessing, J.S., \& Schwartz, S. (2006). Gender differences in high-school students' views of science. International Journal of Science Education, 28(4), 362-381.

Mishra, S., Cellante, D. and Igoche, D. (2016). How to encourage middle school girls interested in STEM+C education: An assessment of current status. Proceedings of the Education Special Interest Group (EDSIG) for Association for Information Technology Professionals (AITP), ISSN: 2473-3857, V2, N4003.

Modi, K., Schoenberg, J., \& Salmond, K. (2012). Generation STEM: What girls are saying about science, technology, engineering, and math. New York: Girl Scouts Research Institute.

Monroe, D. (2014). A new type of mathematics? Communications of the ACM , 57(2), 13 - 15.

National Academy of Engineering (2008). Changing the conversation: Messaging for improving public understanding of engineering. Washington, DC: The National Academies Press.

National Science Foundation. Retrieved from https://www.nsf.gov/funding/pgm_summ.jsp?pims_id=505006

Newman, L., Wagner, M., Cameto, R., \& Knokey, A. (2009). The post-high school outcomes of youth with disabilities up to 4 years after high school. A Report from the National Longitudinal Transition Study-2 (NLTS2) (NCSER 2009-3017). Mento Park, CA: SRI International.

Science Pioneers, retrieved from www.sciencepioneers.org/parentds/why-stem-is-important-to-everyone

Simpkins, S.D., Davis-Kean, P.E., \& Eccles, J.S. (2006). The intersection between self-concept and values: Links between beliefs and choices in high school. New Directions for Child and Adolescent Development, 110, $31-47$.

Stetser, M., \& Stillwell, R. (2014). Public high school four-year on-time graduation rates and event dropout rates: School years 2010-11 and 2011-12. First look (NCES 2014-391).

Tai, R.H., Liu, C.Q., Maltese, A.V., \& Fan, X. (2006). Planning early for careers in science. Science, 312, 11431144.

The 10 fastest-growing careers in the next five years. (2016). Retrieved from fortune.com/2016/06/07/the-10fastest-growing-careers-in-the-next-five-years.

Wilensky, U., Brady, C. E. \& Horn, M.S. (2014). Fostering computational literacy in science classrooms. Communications of the ACM, 57(8), $24-28$. 